REVIEW ARTICLE

PRACA POGLĄDOWA

\title{
ANALYSIS OF MEDICAL SERVICES FINANCIAL EFFICIENCY IN THE SECONDARY CARE INSTITUTIONS OF SUMY REGION
}

DOI: 10.36740/WLek202001132

\author{
Volodymyr I. Potseluiev ${ }^{1,2}$, Olena I. Boiko², Yevhen V. Smiianov ${ }^{2}$, Andriana M. Kostenko² \\ 'SUMY CENTRAL DISTRICT CLINICAL HOSPITAL, SUMY, UKRAINE \\ 2SUMY STATE UNIVERSITY, SUMY, UKRAINE
}

\begin{abstract}
The aim: The aim of the study is to analyze financial indicators and assess the effectiveness of financing secondary medical care enterprises during the transition period in the context of remuneration to doctors.

Materials and methods: To perform the analysis, the financial characteristics of 26 medical facilities have been collected and processed by means of involving the bibliosemantic method, data extract and content analysis.

Conclusions: Presents a comparative analysis of labour payment expenses to doctors of cardiology, obstetric and gynecological and surgical departments of medical facilities. The predicted labour payment expenses for the number of services provided have been calculated. Besides, the article makes it clear that the allocation of funds according to bed-day loads and the number of medical services rendered is unsustainable and does not correspond to the real load on the actual position.
\end{abstract}

KEY WORDS: financing, costs, remuneration, medical institutions

Wiad Lek. 2020;73(1):169-175

\section{INTRODUCTION}

\section{PROBLEM FORMULATION}

The key to the development and prosperity of each country is healthy citizens. Accordingly, healthcare is a priority for improvement and development. Today, the healthcare system is in the process of reforming. Tariff setting system for rendered services which had existed before the reform started and which to some extent retains its function in the transition period did not take into account many factors that eventually affect the quality level of medical services. The financial component of the health care system is divided into funding salaries, administrative expenses, procurement of pharmaceuticals, etc. The financing model proposed by power-makers aims at introducing a state guaranteed package of medical care. It is based on the main principle of changes which consists in the shift from funding cost estimates of medical institutions to payment for the result [1]. Although the implementation of new legislative norms and work systems has been under way not long so far, and it mainly refers to primary health care, currently, we can observe both positive changes and problematic issues that require elaboration and identification of the ways to solve them. Currently, the issue that needs to be thoroughly studied is secondary healthcare financing, that will enable efficient distribution and employment of the funds rendered. At the same time, secondary medical institutions are supported by medical subvention funds from the state and local budgets. There are a lot of health care facilities where funds are spent only on their passive maintenance, or use of funds does not meet improving the quality of medical care and the real workload. Therefore, in order to determine the effectiveness of funding, it is necessary to undertake a thorough cost analysis using the example of remuneration for health professionals.

\section{PUBLICATIONS ANALYSIS}

The issue of medical system and health care reform in Ukraine is being explored by scientists from various fields of science, since these areas have multiple components that are worth analyzing, studying and processing. Publications of various scholars both cover new approaches to work in the face of changes and actively analyze the still operating system. Thus, S.O. Kushnir is considering financial security issues with the problems of financial support in the process of reform, focusing on the level of wages and staffing of medical institutions [2].

I.S. Muzyka when considering the implementation of medical reform on the example of the Carpathian region, Ukraine, concludes that the existing financing mechanism does not fully allow for the specifics and features of a particular region. [3].

I.V. Yaremchuk pays attention to the public internal control over financial flows in the context of healthcare reform. Having conducted the cost analisis for several years, he concluded that, despite increased costs, the overall situation in medicine has not improved significantly [4].

L.V. Hryniv and T.V. Pushik dedicate their research to the issues of medical facility management in the context of medical reform, and conclude that quality services are guaranteed by the availability of skilled and motivated staff, 
Table 1. Labour costs for one treated patient per year, UAN

\begin{tabular}{|c|c|c|c|c|c|c|}
\hline The name of a Medical Facility & $\begin{array}{l}\text { Cash labor } \\
\text { costs (KEKV } \\
2110 \text { ) for 2018, } \\
\text { thousand UAH }\end{array}$ & $\begin{array}{l}\text { Bed capacity } \\
\text { as of } \\
01.01 .2019\end{array}$ & $\begin{array}{l}\text { Number of } \\
\text { patients } \\
\text { treated for } \\
2018\end{array}$ & $\begin{array}{l}\text { Labour } \\
\text { costs per } \\
1 \text { patient, } \\
\text { thousand } \\
\text { UAH }\end{array}$ & $\begin{array}{l}\text { Labour costs } \\
\text { outlook per } 1 \\
\text { patient, UAH, } \\
\text { in terms of } \\
\text { the reform }\end{array}$ & $\begin{array}{l}\text { Percentage } \\
\text { of patients } \\
\text { treated of the } \\
\text { total number } \\
\text { by districts }\end{array}$ \\
\hline $\begin{array}{l}\text { Bilopillia Central District Hospital } \\
\text { (Bilopillia CDH) }\end{array}$ & 10567 & 200 & 6962 & 52,84 & 4859,80 & 4,02 \\
\hline Buryn $\mathrm{CDH}$ & 6910 & 105 & 3764 & 65,81 & 11196,19 & 2,17 \\
\hline Velyka Pysarivka CDH & 5252 & 100 & 2992 & 52,52 & 11240,72 & 1,73 \\
\hline Krasnopillia CDH & 6284 & 125 & 2978 & 50,27 & 10810,17 & 1,72 \\
\hline Krolevets CDH & 10892,9 & 160 & 5013 & 68,08 & 8696,75 & 2,90 \\
\hline Lebedyn CDH & 11277 & 162 & 6264 & 69,61 & 7116,36 & 3,62 \\
\hline Lypova Dolyna CDH & 4503 & 94 & 2592 & 47,90 & 11835,05 & 1,50 \\
\hline Nedryhailiv CDH & 6975 & 100 & 3713 & 69,75 & 12029,58 & 2,15 \\
\hline Putyvl CDH & 9194 & 135 & 3893 & 68,10 & 11202,56 & 2,25 \\
\hline Seredyno-Buda CDH & 4957 & 94 & 2528 & 52,73 & 13358,11 & 1,46 \\
\hline $\begin{array}{l}\text { MNO “Sumy CDCH” of SDC, SR } \\
\text { (Municipal Non-Commercial } \\
\text { Organization “Sumy Central } \\
\text { District Clinical Hospital” of Sumy } \\
\text { District Council, Sumy Region }\end{array}$ & 11062 & 215 & 7291 & 51,45 & 4518,97 & 4,21 \\
\hline Yampil CDH & 4737 & 91 & 3050 & 52,05 & 10929,32 & 1,76 \\
\hline $\begin{array}{l}\text { MF (Municipal Facility) “Sumy } \\
\text { City Clinical Hospital № 1” }\end{array}$ & 25485 & 360 & 12315 & 70,79 & 3681,11 & 7,12 \\
\hline $\begin{array}{c}\text { MNO “Clinical Hospital № 4" of } \\
\text { SCC (Sumy City Council) }\end{array}$ & 8745 & 130 & 6040 & 67,27 & 7131,99 & 3,49 \\
\hline $\begin{array}{l}\text { MF (Municipal Facility) “Sumy } \\
\text { City Clinical Hospital № 5" }\end{array}$ & 22557 & 330 & 10928 & 68,35 & 4005,51 & 6,31 \\
\hline $\begin{array}{c}\text { MNO “The St Zinaida Children's } \\
\text { Hospital” of SCC }\end{array}$ & 20331 & 295 & 10729 & 68,92 & 4113,47 & 6,20 \\
\hline $\begin{array}{l}\text { MNO "The Blessed Virgin Mary } \\
\text { Clinical Maternity Hospital" of } \\
\text { SCC }\end{array}$ & 11552 & 165 & 4566 & 70,01 & 9819,03 & 2,64 \\
\hline Konotop CDH & 33392 & 521 & 19718 & 64,09 & 2081,48 & 11,39 \\
\hline $\begin{array}{c}\text { MNO of KCC "Konotop City } \\
\text { Hospital" }\end{array}$ & 6132 & 110 & 4308 & 55,75 & 8286,38 & 2,49 \\
\hline Romny CDH & 23892 & 350 & 12837 & 68,26 & 3405,27 & 7,42 \\
\hline Shostka CDH & 22860 & 340 & 11418 & 67,24 & 3770,84 & 6,60 \\
\hline $\begin{array}{l}\text { MNO “Shostka Children's } \\
\text { Hospital" of Shostka } \\
\text { City Council }\end{array}$ & 4496 & 65 & 2090 & 69,17 & 21193,26 & 1,21 \\
\hline Okhtyrka CDH & 17642 & 326 & 12462 & 54,12 & 2780,82 & 7,20 \\
\hline Hlukhiv CDH & 19529,75 & 265 & 8477 & 73,70 & 5567,24 & 4,90 \\
\hline Trostianets City Hospital & 11660 & 170 & 6145 & 68,59 & 7147,58 & 3,55 \\
\hline
\end{tabular}

Note: Compiled by the authors according to the data from [14].

and applying a value-based healthcare system at the micro level allows to achieve cost savings, to improve the quality of medical services, and at the state level - to increase health care efficiency [5].

V.A. Smiianov developed and implemented a model of internal audit at the institution of health care. This mechanism helps to optimize financial, organizational and treatment processes in hospitals, leading to improved quality of care. [6].

T. Zhelyuk talks about the scientific and applied aspects of work, which should be aimed at effectiveness capable of contributing to the development of competitiveness at medical institutions. For this purpose, it is required to have a resource 
Table 2. Activity analysis of inpatient obstetric and gynecological departments per one actual permanent positions, UAN

\begin{tabular}{|c|c|c|c|c|c|c|c|c|c|c|}
\hline 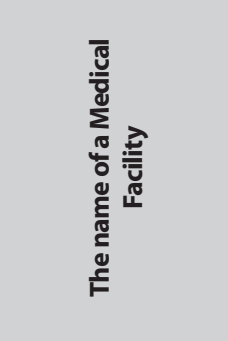 & 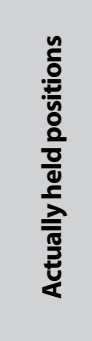 & 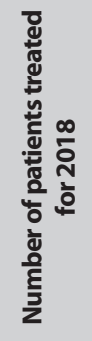 & 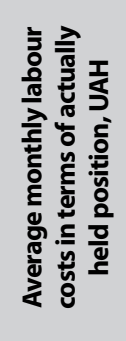 & 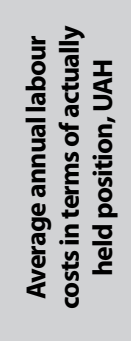 & 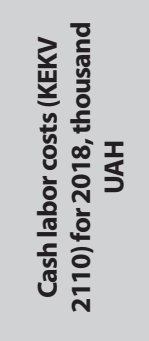 & 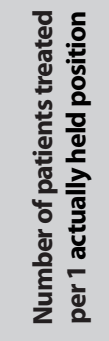 & 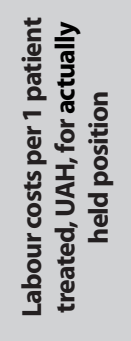 & 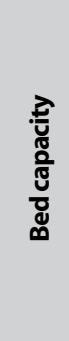 & 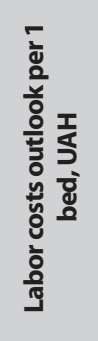 & 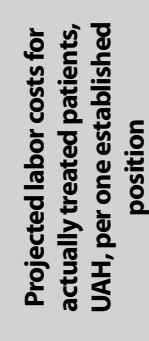 \\
\hline Bilopillia CRH & 3,75 & 672 & 10602 & 127224 & 477090 & 179,20 & 709,96 & 20 & 11,01 & 66304,00 \\
\hline Buryn CDH & 1,5 & 561 & 7161 & 85932 & 128898 & 374,00 & 229,76 & 15 & 9,89 & 138380,00 \\
\hline $\begin{array}{c}\text { Velyka Pysarivka } \\
\mathrm{CDH}\end{array}$ & 1,25 & 674 & 27878 & 334536 & 418170 & 539,20 & 620,43 & 18 & 9,88 & 199504,00 \\
\hline Krasnopillia CDH & 1 & 261 & 9850 & 118200 & 118200 & 261,00 & 452,87 & 15 & 21,26 & 96570,00 \\
\hline Krolevets CDH & 5,5 & 630 & 6609 & 79308 & 436194 & 114,55 & 692,37 & 18 & 10,57 & 42381,82 \\
\hline Lebedyn CDH & 5 & 683 & 9288 & 111456 & 557280 & 136,60 & 815,93 & 14 & 7,58 & 50542,00 \\
\hline $\begin{array}{c}\text { Lypova Dolyna } \\
\text { CDH }\end{array}$ & 1 & 247 & 16175 & 194100 & 194100 & 247,00 & 785,83 & 15 & 22,47 & 91390,00 \\
\hline Putyvl CDH & 3,25 & 642 & 24079 & 288948 & 939081 & 197,54 & 1462,74 & 25 & 14,41 & 73089,23 \\
\hline Sumy CDCH & 1,5 & 773 & 8817 & 105804 & 158706 & 515,33 & 205,31 & 20 & 9,57 & 190673,33 \\
\hline Yampil CDH & 2 & 683 & 7017 & 84204 & 168408 & 341,50 & 246,57 & 16 & 8,67 & 126355,00 \\
\hline $\begin{array}{c}\text { MF“Sumy City } \\
\text { Clinical Hospital } \\
\text { № 1" }\end{array}$ & 6,5 & 1632 & 6560 & 78720 & 511680 & 251,08 & 313,53 & 40 & 9,07 & 92898,46 \\
\hline $\begin{array}{c}\text { MF"Sumy City } \\
\text { Clinical Hospital } \\
\text { № 5" }\end{array}$ & 9 & 1474 & 5404 & 64848 & 583632 & 163,78 & 395,95 & 30 & 7,53 & 60597,78 \\
\hline $\begin{array}{c}\text { MNO “The } \\
\text { Blessed Virgin } \\
\text { Mary Clinical } \\
\text { Maternity } \\
\text { Hospital" of SCC }\end{array}$ & 208,5 & 4566 & 4598 & 55176 & 11504196 & 21,90 & 2519,53 & 165 & 13,37 & 8102,73 \\
\hline Konotop CDH & 14 & 2188 & 16995 & 203940 & 2855160 & 156,29 & 1304,92 & 65 & 10,99 & 57825,71 \\
\hline Romny CDH & 11,5 & 2034 & 14912 & 178944 & 2057856 & 176,87 & 1011,73 & 50 & 9,10 & 65441,74 \\
\hline Shostka CDH & 20,25 & 1756 & 11826 & 141912 & 2873718 & 86,72 & 1636,51 & 60 & 12,64 & 32084,94 \\
\hline Okhtyrka CDH & 10,75 & 1118 & 5881 & 70572 & 758649 & 104,00 & 678,58 & 33 & 10,92 & 38480,00 \\
\hline Hlukhiv CDH & 7,5 & 1687 & 12738,6 & 152863 & 1146474 & 224,93 & 679,59 & 38 & 8,33 & 83225,33 \\
\hline $\begin{array}{c}\text { Trostianets City } \\
\text { Hospital }\end{array}$ & 6 & 861 & 10003 & 120036 & 720216 & 143,50 & 836,49 & 25 & 10,74 & 53095,00 \\
\hline
\end{tabular}

Note: Compiled by the authors according to the data from [14].

base for functional activity, to strengthen the internal factors of competitiveness, such as medical efficiency, that is, the ability to meet the needs of patients by providing a full range of high-quality medical services and administrative effectiveness, including the effectiveness of administrative, financial, personnel, information and communication management [7].

S. Knysh considers the problems of medical reform from the point of view of legal regulation and speaks about the prevention of corruption in the management process. In his work, he says that corruption largely depends on the level of material security of medical professionals themselves. Adequate cash security together with the increased legal liability significantly facilitate the prevention of corruption offenses.
The scientist emphasizes the main problem consisting in the fact that it is incorrect to require transparency and honesty in work whereas financing does not correspond to the complexity of the acquired profession. Medical reform is aimed at taking measures to remedy this situation, in particular, by improving the working conditions of health workers [8].

\section{THE AIM}

The aim of the study is to analyze financial indicators and assess the effectiveness of financing secondary medical care enterprises during the transition period in the context of remuneration to doctors. 
Table 3. Labour costs for childbirth in a maternity ward per one actual established (permanent) positions, UAN

\begin{tabular}{|c|c|c|c|c|c|c|c|c|c|}
\hline 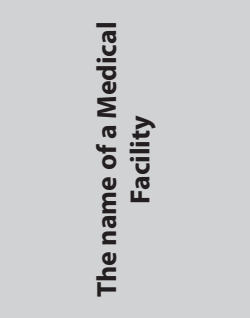 & 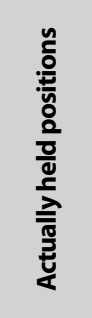 & 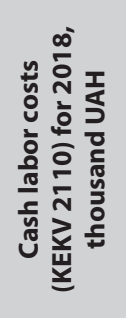 & 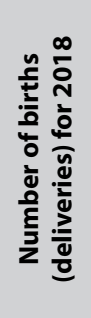 & 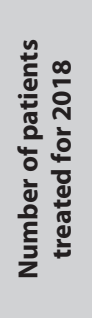 & 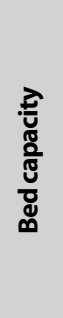 & 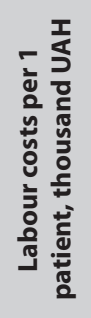 & 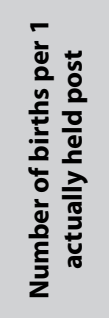 & 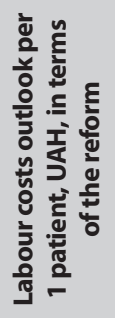 & 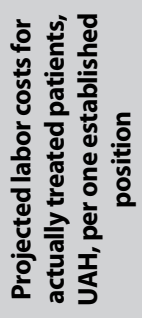 \\
\hline $\begin{array}{c}\text { Velyka Pysarivka } \\
\text { CDH }\end{array}$ & 0,75 & 750 & 33 & 37 & 8 & 20,27 & 44,00 & 80,00 & 16280,00 \\
\hline Putyvl CDH & 1,5 & 1144 & 85 & 205 & 10 & 5,58 & 56,67 & 18,05 & 20966,67 \\
\hline Yampil CDH & 1 & 561 & 73 & 285 & 6 & 1,97 & 73,00 & 7,79 & 27010,00 \\
\hline $\begin{array}{l}\text { MNO “The Blessed } \\
\text { Virgin Mary } \\
\text { Clinical Maternity } \\
\text { Hospital” of SCC }\end{array}$ & 61 & 3366 & 1854 & 1860 & 75 & 1,81 & 30,39 & 14,92 & 11245,57 \\
\hline Konotop CDH & 12 & 3484 & 695 & 1062 & 35 & 3,28 & 57,92 & 12,19 & 21429,17 \\
\hline Romny CDH & 9,75 & 3086 & 404 & 1130 & 30 & 2,73 & 41,44 & 9,82 & 15331,28 \\
\hline Shostka CDH & 16,25 & 4373 & 459 & 617 & 30 & 7,09 & 28,25 & 17,99 & 10451,08 \\
\hline Hlukhiv CDH & 3,25 & 2022,8 & 362 & 952 & 19 & 2,12 & 111,38 & 7,38 & 41212,31 \\
\hline
\end{tabular}

Note: Compiled by the authors according to the data from [14]

\section{MATERIALS AND METHODS}

In order to assess cost-effectiveness of medical services, we have analyzed the financial performance of inpatient departments of Sumy region's medical clinics rendering secondary medical care. These figures concern payroll costs to physicians. In total, 26 institutions are subordinated to the healthcare department of Sumy Regional State Administration.

Our computations are based on the following criteria: cash labour costs, average monthly labour costs per an actually held position, the number of patients treated, as well as bed capacity. The study was conducted with involving the bibliosemantic method, content analysis and data extract.

\section{REVIEW AND DISCUSSION}

In Ukraine, medical reform started with the adoption of the Laws "On State Financial Guarantees of Medical Services for the Population" of October 19, 2017, which entered into force on January 30, 2018, and "On Amendments to Some Legislative Acts of Ukraine on Improving Legislation on the Activities of Health Care Institutions" dated 06.04.2017, which came into force on 06.11.2017 [9]. This law provides for a change in the legal status of healthcare institutions to municipal non-commercial organizations (non-profit utility companies) that will enable to independently manage administrative, financial and business activities. The cardinal change in the reform is the transition from the completely state-subsidized medical institutions to public funding of particular health care services. Accordingly, the National Health Service of Ukraine has been established. It is a governing body that pays money to medical facilities for their services provided. Under the Medical Guarantee Program, citizens are ensured to have full payment at the expense of the state budget [10]. According to this law, a uniform tariff for medical service payment has been set. It may sustain modifications in compliance with coefficients. Change in funding system began with primary health care. An important component of the reform is the remuneration to health workers. However, in the transition period, secondary healthcare funding is still being carried out by the current system (at the expense of local budgets) [11].

Changes to the secondary health facilities are gradually entering into force. The key point of this reform is the modification of healthcare financing system, which consists in channeling funds for the services rendered by a healthcare facility to a particular patient. To calculate the cost of a service, the following indicators must be taken into account: the total budget allotment for the healthcare system, the cost of a particular service, and the need for a given service [12]. As of today, hospital financing is calculated on the basis of the number of people living on the territory accountable to a particular healthcare facility per inhabitant. The amount of financing for hospital maintenance on the state and local budgets is determined by the established economic norms and standards, based on bed capacity by a specific disease profile. It is according to those standards that the required number of doctors, mid-level and junior medical personnel, salary funds, costs on medications, nutrition, etc. are identified [13]. The amount of payment is formed on the basis of official salaries, which are approved by the Cabinet of Ministers of Ukraine. That is, healthcare workers are paid for the hours worked, but not for the volume of services rendered. This approach results in the lack of motivation in for healthcare employees to improve the quality of care and care. The existing load on hospital beds does not take into account the practical need for their number and duration of inpatient treatment without regard to the profile of hospital department, where in order to maintain the funding level, the unreasonable bed capacity is available. 
Table 4. Activity analysis of inpatient surgical departments per one actually held established positions, UAN

\begin{tabular}{|c|c|c|c|c|c|c|c|c|c|}
\hline 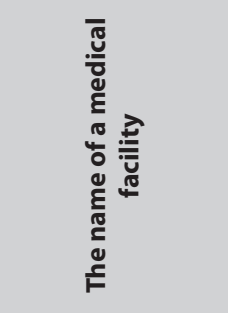 & 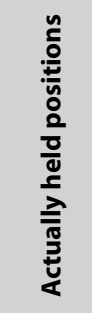 & 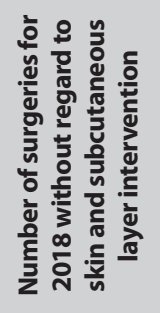 & 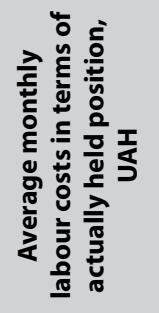 & 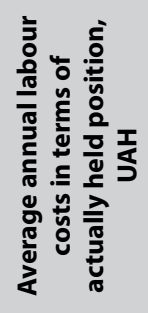 & 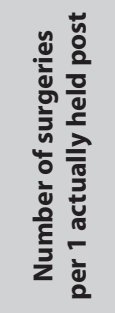 & 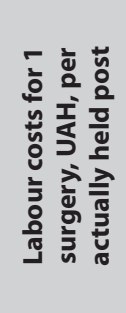 & 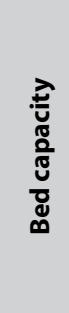 & 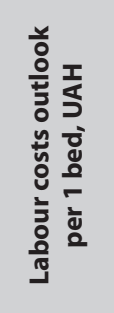 & 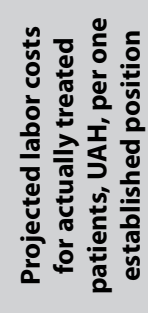 \\
\hline Bilopillia CDH & 5,5 & 135 & 6829 & 81948 & 24,55 & 3338,62 & 25 & 68,52 & 9081,82 \\
\hline Buryn CDH & 2 & 205 & 9129 & 109548 & 102,50 & 1068,76 & 25 & 45,12 & 37925,00 \\
\hline $\begin{array}{c}\text { Velyka } \\
\text { Pysarivka CDH } \\
\end{array}$ & 1 & 150 & 16933 & 203196 & 150,00 & 1354,64 & 22 & 54,27 & 55500,00 \\
\hline $\begin{array}{c}\text { Krasnopillia } \\
\mathrm{CDH}\end{array}$ & 1,5 & 73 & 13928 & 167136 & 48,67 & 3434,30 & 15 & 76,03 & 18006,67 \\
\hline Krolevets CDH & 6,5 & 188 & 8559 & 102708 & 28,92 & 3551,07 & 45 & 88,56 & 10701,54 \\
\hline Lebedyn CDH & 6,5 & 196 & 8149 & 97788 & 30,15 & 3242,97 & 26 & 49,08 & 11156,92 \\
\hline $\begin{array}{c}\text { Lypova Dolyna } \\
\text { CDH }\end{array}$ & 2,5 & 77 & 13331 & 159972 & 30,80 & 5193,90 & 19 & 91,30 & 11396,00 \\
\hline $\begin{array}{c}\text { Nedryhailiv } \\
\mathrm{CDH}\end{array}$ & 4 & 178 & 12675 & 152100 & 44,50 & 3417,98 & 31 & 64,44 & 16465,00 \\
\hline Putyvl CDH & 4,75 & 290 & 12079 & 144948 & 61,05 & 2374,15 & 30 & 38,28 & 22589,47 \\
\hline $\begin{array}{c}\text { Seredyno-Buda } \\
\text { CDH }\end{array}$ & 4,25 & 142 & 9673 & 116076 & 33,41 & 3474,11 & 30 & 78,17 & 12362,35 \\
\hline $\begin{array}{c}\text { MNO “Sumy } \\
\mathrm{CDCH}^{\prime \prime} \text { of SDC, } \\
\text { SR }\end{array}$ & 3,5 & 589 & 6943 & 83316 & 168,29 & 495,09 & 35 & 21,99 & 62265,71 \\
\hline Yampil CDH & 2,5 & 116 & 9870 & 118440 & 46,40 & 2552,59 & 25 & 79,74 & 17168,00 \\
\hline $\begin{array}{c}\text { MF "Sumy City } \\
\text { Clinical Hospital } \\
\text { № 1" }\end{array}$ & 9,75 & 640 & 8179 & 98148 & 65,64 & 1495,22 & 40 & 23,13 & 24287,18 \\
\hline $\begin{array}{c}\text { MF "Sumy City } \\
\text { Clinical Hospital } \\
\text { № 5" }\end{array}$ & 18,25 & 937 & 18482 & 221784 & 51,34 & 4319,70 & 110 & 43,44 & 18996,71 \\
\hline Konotop CDH & 13 & 738 & 7372 & 88464 & 56,77 & 1558,31 & 70 & 35,09 & 21004,62 \\
\hline $\begin{array}{c}\text { MNO of KCC } \\
\text { "Konotop City } \\
\text { Hospital" }\end{array}$ & 4 & 97 & 10373 & 124476 & 24,25 & 5133,03 & 45 & 171,65 & 8972,50 \\
\hline Romny CDH & 14 & 761 & 8524 & 102288 & 54,36 & 1881,78 & 47 & 22,85 & 20112,14 \\
\hline Shostka CDH & 12 & 664 & 7074 & 84888 & 55,33 & 1534,12 & 50 & 27,86 & 20473,33 \\
\hline Okhtyrka CDH & 9,5 & 456 & 8680 & 104160 & 48,00 & 2170,00 & 55 & 44,63 & 17760,00 \\
\hline Hlukhiv CDH & 6,75 & 298 & 8244,4 & 98933 & 44,15 & 2240,93 & 48 & 59,60 & 16334,81 \\
\hline $\begin{array}{c}\text { Trostianets City } \\
\text { Hospital }\end{array}$ & 5,5 & 202 & 12289 & 147468 & 36,73 & 4015,22 & 30 & 54,95 & 13589,09 \\
\hline
\end{tabular}

Note: Compiled by the authors according to the data from [14].

Labor costs per one person treated at secondary healthcare hospitals for 2018 presented in Table 1 on average have the following characteristics:

Table 1 clearly shows that bed capacity in hospitals has significant differences, as this figure is mainly calculated in accordance with the average annual population in regions. However, labour costs per patient are different. For example, comparing two medical establishments - Bilopillia Central District Hospital, which has 200 beds, and the number of treated is 6962 people, and Nedryhailiv Central District Hospital, where 100 beds and 3713 treated, the salary costs are 52,84 thousand UAN per year and 69.75 thousand UAN per year respectively. We can see that, compared to the Nedryhailiv $\mathrm{CDH}$, the Bilopillia $\mathrm{CDH}$ has twice the load, but receives $24.24 \%$ less labourl costs. This discrepancy exists in other institutions.

A significant element of the Medical Guarantee Program will be medical services related to childbirth, treatment 
Table 5. Activity analysis of inpatient cardiac departments per one actually held established position, UAN

\begin{tabular}{|c|c|c|c|c|c|c|c|c|c|c|}
\hline 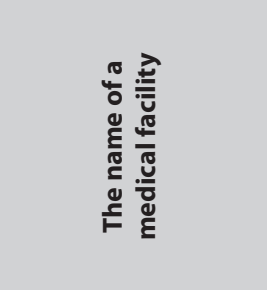 & 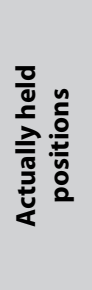 & 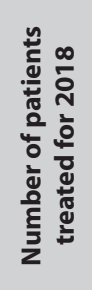 & 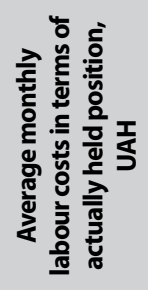 & 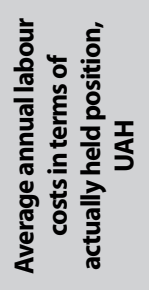 & 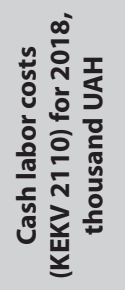 & 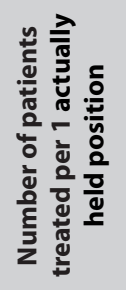 & 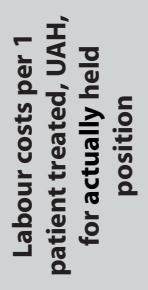 & 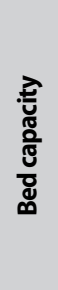 & 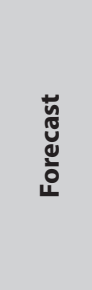 & 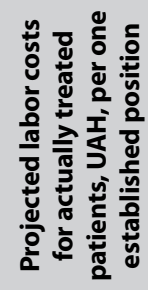 \\
\hline Lebedyn CDH & 2,25 & 1294 & 6596 & 79152 & 178 & 575,11 & 137,63 & 33 & 9,44 & 212791,11 \\
\hline $\begin{array}{c}\text { MNO "Sumy CDCH" } \\
\text { of SDC, SR }\end{array}$ & 3 & 929 & 4811 & 57732 & 173 & 309,67 & 186,43 & 30 & 11,95 & 114576,67 \\
\hline $\begin{array}{c}\text { MF 'Sumy City } \\
\text { Clinical Hospital } \\
\text { № 1' }\end{array}$ & 5 & 847 & 5143 & 61716 & 309 & 169,40 & 364,32 & 30 & 13,11 & 62678,00 \\
\hline $\begin{array}{c}\text { MF “Sumy City } \\
\text { Clinical Hospital } \\
\text { № 5" }\end{array}$ & 2,25 & 166 & 4044 & 48528 & 109 & 73,78 & 657,76 & & 0,00 & 27297,78 \\
\hline Konotop $\mathrm{CDH}$ & 3 & 1592 & 6250 & 75000 & 225 & 530,67 & 141,33 & 45 & 10,46 & 196346,67 \\
\hline Romny CDH & 2 & 975 & 6496 & 77952 & 156 & 487,50 & 159,90 & 30 & 11,38 & 180375,00 \\
\hline Shostka CDH & 2 & 795 & 6368 & 76416 & 153 & 397,50 & 192,24 & 25 & 11,64 & 147075,00 \\
\hline
\end{tabular}

Note: Compiled by the authors according to the data from [14].

of cardiovascular diseases, screening for early detection of cancer, etc. Taking the example of obstetric and gynecological, cardiac, and surgical wards we can analyze the pre-reform payments and predict the total costs that healthcare establishments will be able to receive after reforming the financial relationships. The data are presented in Table 2 and Table 3.

Table 2 says that the number of patients per 1 actually held position makes a big difference, and labour costs do not match the actual workload. For example, the cost of remuneration per 1 patient treated in Bilopillia $\mathrm{CDH}$ is $\mathrm{UAH}$ 709.96, and the number of patients treated per 1 actually held position is 179.2 people. At that time, in Buryn $\mathrm{CDH}$ labor costs per 1 patient treated is UAH 229.76, and the number of patients treated per 1 actually held position is 374 people. The Shostka CDH has completely inappropriate figures - the cost of remuneration per 1 patient treated is 1636.51 UAH, while the number of patients treated per 1 actually held position is only 86.72 people.

We also analyzed those facilities that provide only obstetric services with regard to delivery costs. There are only 8 of them in Sumy region. Table 3 covers the available and projected indicators.

As we can see, there exists inconsistency and imbalance as to the load on maternity wards within district hospitals of the region. In order to optimize hospital departments and the rate of expenditure, as well as to increase the level of qualified assistance for childbirth, the minimum safe load will be determined. It is considered that 200 childbirths per year for one ward is insufficient for physicians to maintain the required level of qualification, and as the WHO has estimated, the minimum required number of childbirths should be 500 in order to be safe [15]. Table 3 shows that two of eight medical facilities departments have got more than 500 childbirths. But three of them do not exceed even 100 childbirths but labor costs are higher than in those departments which have got more than 500 cases.

A similar discrepancy situation is observed in surgery and cardiology departments, which is presented in Table 4 and Table 5.

Also remarcable is the situation with bed capacity. Having an equal load on the bed fund (Bilopillia, Buryn and Yampil $\mathrm{CDHs}$ ), there is a big difference between the actually held positions and the number of surgeries fulfilled, and again we can see the fact that the workload does not match the labour costs.

We can conclude that the load on one permanent post at remuneration of labor in different hospitals within the same type of medical care does not correspond to the number and quality of services provided. It is obvious that labour costs are insufficient. It means if there are more patients treated then there is less expenditure on wages. It causes the absence of motivation that results in quality of health services.

\section{CONCLUSIONS}

Analyzing projected labor costs for actually treated patients per one established position it is necessary to mention that they can become quite sufficient and would create competitive atmosphere in healthcare industry.

The reform of the health care system is primarily aimed at improving the quality of healthcare support. The introduction of secondary healthcare reform, which is gradually extending, will contribute to a significant redistribution of financial flows, which will significantly improve the quality and accessibility of health care. However, because of the ongoing transition process, financial activity in health 
care facilities remains the same, that causes inappropriate and irrational resource utilization and is subject to careful analysis and further advanced academic research.

\section{REFERENCES}

1. https://www.kmu.gov.ua/ua/npas/249626689/[Dostep: 13.09.2019]

2. Kushnir S. 0., Onipko A. D. Medychna reforma v Ukraini: problemy finansuvannia, analiz perspektyv ta naslidkiv [Healthcare reform in Ukraine - issue of financing, examination of prospects and consequences]. Ekonomichnyi prostir. 2018; 132:61-71.(In Ukrainian).

3. Muzyka I. S. Reforma okhorony zdorovia: problemy, analiz, naslidky realizatsii (na prykladi Karpatskoho rehionu Ukrainy) [Health care reform: problems, analysis, implementation trends (for example of the Carpathian region of Ukraine]. Sotsialno-ekonomichni problemy suchasnoho periodu Ukrainy.2016;2:38-42.(In Ukrainian).

4. laremchuk I. V. Derzhavnyi vnutrishnii finansovyi kontrol v umovakh reformuvannia haluzi okhorony zdorovia [State internal financing control in the conditions of reforming the healthcare industry branch of Ukraine]. Zbirnyk naukovykh prats Universytetu derzhavnoi fiskalnoi sluzhby Ukrainy. 2018;2:408-422. (In Ukrainian).

5. Hryniv L.V., PushykT.V. Udoskonalennia menedzhmentu poliklinichnykh zakladiv v umovakh provedennia medychnoi reform [Improvement of management of polyclinic institutions in the conditions of medical reform].Visnyk Prykarpatskoho universytetu. Ekonomika. 2018;XIII:130136. (In Ukrainian).

6. Smiianov V.A., Tarasenko S., Smiianova 0. Development and implementation of the internal audit mechanisms to be used in the health care facilities. Georgian medical news. 2013; 6(219):58-61.

7. Zheliuk T. Finansovi aspekty funktsionuvannia rynku medychnykh posluh ta zakupivil likiv [Financial aspects of functioning of the market of medical services and purchasing of medicines]. Rehionalni aspekty rozvytku produktyvnykh syl Ukrainy. 2018;23:113-117. (In Ukrainian).

8. Knysh S. Udoskonalennia publichnoho upravlinnia sferoiu okhorony zdorovia v Ukraini: analiz reformy ta evroperspektyvy [Improving public health management in Ukraine: analysis of reforms and European perspectives]. Aktualni problemy pravoznavstva. 2019; 1:54-59. (In Ukrainian).

9. https://zakon2.rada.gov.ua/laws/show/2002-19 [Dostep: 13.09.2019]

10. https://zakon.rada.gov.ua/laws/show/2168-19 [Dostep: 13.09.2019]

11. Boiko S. H. Dyversyfikatsiia dzherel finansuvannia okhorony zdorovia [Diversification of health funding sources]. URL: https://niss.gov.ua/ doslidzhennya/analitichni-materiali/socialna-politika/diversifikaciyadzherel-finansuvannya (In Ukrainian).
12. Reforma okhorony zdorovia [Health care reform]. URL: https://www. mcmed.ua/ua/articles (In Ukrainian). [Dostep: 18.09.2019]

13. Vikhrov 0. P. Finansove pravo. In: Vikhrov 0.P. Chernihiv: ChDIEU; 2002, 280. (In Ukrainian).

14. Departament finansiv Sumskoi oblasnoi derzhavnoi administratsii. URL: http: //finansy.sm.gov.ua/index.php/uk/[Dostep: 10.09.2019]

15. Petrenko 0 . Zminy - 2020. Yak ne propustyty maibutnie [Changes - 2020. How not to miss the future]. Natsionalna medychna stinnivka.2019;1:1-5. URL: https://www.medsprava.com.ua/files/ Articles\%20MEDSPRAVA/1761/14312moz_digest_17_2019_1.pdf (In Ukrainian). [Dostep: 21.09.2019]

\section{ORCID and contributionship:}

Volodymyr I. Potseluiev - 0000-0003-2140-4058 A,B,E,F

Olena I. Boiko - 0000-0002-7457-4280 D,F

Yevhen V. Smiianov - 0000-0003-4996-1550 E,F

Andriana M. Kostenko - 0000-0002-8970-4244 ${ }^{B}$

\section{Conflict of interest:}

The Authors declare no conflict of interest

\section{CORRESPONDING AUTHOR Yevhen V.Smiianov \\ Sumy State University \\ Rymskoho-Korsakova St., 2, 40007 Sumy, Ukraine \\ e-mail:v.smiyanov@med.sumdu.edu.ua}

Received: 17.08 .2019

Accepted: 10.12 .2019

\footnotetext{
A - Work concept and design, B - Data collection and analysis, C - Responsibility for statistical analysis,

D-Writing the article, $\mathbf{E}$-Critical review, $\mathbf{F}$ - Final approval of the article
} 